\title{
Toleransi Beragama Sebagai Pendekatan Misi Kristen Di Indonesia
}

\author{
Mario Chlief Taliwuna \\ Sekolah Tinggi Teologi Yerusalem Baru Manado \\ mariotaliwuna@gmail.com \\ Veydy Yanto Mangantibe \\ Sekolah Tinggi Teologi Yerusalem Baru Manado \\ Korespondensi:vmangantibe90@gmail.com
}

\begin{abstract}
This article discusses religious tolerance as a mission approach in Indonesia. Religious toleranceis not sufficient to respond only to the attitude of acknowledging and accepting reality indifferent beliefs. But it must also be understood as a way that is formed in the attitude of socialinteraction which recognizes that they must need other people in their differences. If not, thenthey will be faced with problems of personal beliefs driven by different teaching understandingswhich lead to conflict in the division of the nation. This article uses a qualitative approach with adescriptive analysis method. Religious tolerance is one of the Equot;assetsEquot; for the creation of the Unitary State of the Republic of Indonesia (NKRI) in different ethnicities, cultures and religions. The religious tolerance that exists in Indonesian society is an opportunity to bring peace with theform of accommodation in the form of social interactions to avoid conflict which results in thedivision of the nation so that this has an impact on the peace and harmony of nations in differentbeliefs. This is also a form of mission approach with an attitude of faith that brings peace to God love in the midst of differences in ethnicity, culture and religious beliefs.
\end{abstract}

Keywords: religious tolerance; mission approach; indonesia

\begin{abstract}
Abstrak
Artikel ini membahas mengenai toleransi beragama sebagai pendekatan misi di Indoensia: Toleransi agama tidak cukup hanya direspon dengan sikap mengakui dan menerima kenyataan dalam keyakinan yang berbeda, namun harus dipahami sebagai cara yang terbentuk dalam sikap interaksi sosial yang mengakui bahwa mereka harus membuthkan orang lain dalam perbedaan, jika tidak maka akan diperhadapkan dengan maslah-masalah keyakinan pribadi yang didorong dengan pemahaman pengajaran yang berbeda yang mengikibatkan konflik pada perpecahan bangsa. Adapun artikel ini menggunakan pendekatan kualitatif dengan metode deskriptif analisis. Toleransi beragama adalah salah satu "modal" bagi terciptanya Negara Kesatuan Republik Indonesia (NKRI) dalam berbedaan suku, budaya dan agama. Sikap toleransi agama yang ada di tengah masyarakat Indonesia, merupakan kesempatan untuk membawa damai dengan bentuk akomodasi dalam wujud interkasi sosial demi menghidari konflik yang mengikibatkan pada perpecahan bangsa sehingga hal ini berdampak pada kedamaiaan dan kerhamonisan berbangsa dalam keyakinan yang berbeda. Tentunya ini juga sebagai bentuk pendekatan misi dengan sikap iman yang membawa damai kasih Allah ditengah-tengah perbedaan suku, budaya dan keyakinan agama.
\end{abstract}

Kata Kunci: toleransi beragama; pendekatan misi; indonesia 


\section{Pendahuluan}

Toleransi beragama memiliki pengaruh penting sabagai pendakatan terciptanya kerukunan. Persoalanya adalah terletak pada perbedaan suku, budaya dan agama memberikan dampak yang cukup tegas untuk ditanggapi, oleh karena terjadinya ketidakseimbangan yang menimbulkan beberapa konflik antar umat beragama yang berpotensi pada perpecahan bangsa. Biasanya yang terjadi pada krisis toleransi agama yang ssangat memungkinkan untuk terjadinya perpecahan bangsa mengingat Indonesia memliliki beberapa agama yaitu Islam, Kristen, katolik, Hindu, Budha dan konghuchu, seharusnya agama merupakan pedoman moral seseorang untuk saling menghargai dan menghormati satu dengan yang lain tetapi kenyataan menunjukan sebaliknya bahwa kehadiran agama sudah tidak lagi berfungssi sebagai pengarah jalan rohani yang benar maka yang terjadi adalah konflik agama dengan mengatakan bahwa ajaran agama tertentu saja yang paling benar dan agama yang lain salah, radikalisme, terorisme yang berdampak ketidakharmonisan antar umat beragama yang memungkinkan kerugian bagi bangsa dan Negara. Persoalan yang sama diungkapkan oleh Dewi Anggraeni dalam jurnal Studi Al-quran, Ironisnya setiap orang tidak adanya saling menghargai satu dengan yang lain, meraasa diri paling benar dari semua aspek hidup dan orang lain itu salah. ${ }^{1}$

Bangsa Indonesia juga diketahui sebgai bangsa yang menjemuk itu disebabkan oleh karena adanya perbedaan etnis, suku, agama, bahasa, budaya dan adat-istiadat. Perlu juga adanya kekuatan hukum untuk mengatur sikap toleransi yang ada di Indonesia, oleh karena ada beberapa orang yang memiliki pemahaman yang salah atau kurangnya pengatahuan tentang toleransi agama maka perlu adanya aturan hukum yang mengaturnya. Indonesia tidaklah teokrasi justru secara konstitusional Negara yang mengharuskan rakyatnya untuk memeluk satu dari sekian agama yang ada dan di yakini keberadaannya dan itu jelas tertuang dalam pasalh 29 ayat (1) dan (2) UUD 1945. Negara memberikan kebebasan kepada rakytanya memutuskan untuk menentukan satu agama menjadi keyakinannya apakah itu Islam, Kristen, Katolik, Hindu, Budha dan konghuchu, kenyataan ini dengan sendirinya memaksa Negara untuk melibatkan dalam menata kehidupan beragama. Ketentuan dalam pasal 29 UUD 1945 sangat penting artinya bagi agama dan para pemeluknya karena telah memeberi jaminan dan saran dalam keterlibatan umat untuk mengisi dan memperkaya kehidupan berbangsa. ${ }^{2}$ Terciptanya kebebasan disetiap pemeluk agama untuk mendapatkan hak mejalankan keyakinannya dengan ajaran agama masing-masing, maka pengembangan agama dan kehidupan beragama tidak boleh menjurus kearah tumbuhnya pemikiran dan pemahaman agama yang sempit karena hal ini akan menimbulkan konflik antar agama.

Toleransi agama adalah toleransi rumusan keyakinan pada diri manusia berhubungan dengan nilai-nilai yang terkandung dalam ajaran agamanya. ${ }^{3}$ Jika demikian berarti toleransi agama juga dimengerti merupakan realisasi dari sebuah ekspresi keyakian serta pengalaman seseorang yang menganut agamanya dalam bentuk komunitas yang memiliki perbedaan keyakinan tapi tetap pada kebersamaan, maka toleransi agama wujud dari sebuah pendekatan sosial untuk dapat meyakinkan kenormalan hubungan satu dengan yang lain dari paksaan ideologis atau bahkan bentrokan fisik dari masyarakat, dengan manyadari bahwa sesama manusia memerlukan perbedaan yang ada karena pada dasarnya manusia

${ }^{1}$ Dewi Anggraeni and Siti Suhartinah, "Toleransi Antar Umat Beragama Perspektif KH. Ali Mustafa Yaqub," Jurnal Studi Al-Qur'an 14, no. 1 (2018): 59-77.

2 Lely Nisvilyah, "Toleransi Antarumat Beragama Dalam Memperkokoh Persatuan Dan Kesatuan Bangsa (Studi Kasus Umat Islam Dan Kristen Dusun Segaran Kecamatan Dlanggu Kabupaten Mojokerto)," Kajian Moral dan Kewarganegaraan 2, no. 1 (2013): 382-396.

3 Casram Casram, "Membangun Sikap Toleransi Beragama Dalam Masyarakat Plural," Wawasan: Jurnal Ilmiah Agama Dan Sosial Budaya 1, no. 2 (2016): 187-198. 
diciptakan sebagai makhluk sosial, hal ini tentunya juga menjadi satu pendekatan misi untguk membawa damai kasih Yesus bagi bangsa Indonesia. Maka dengan demikian sedapat mungkin menghindari konfilik agama yang berdampak pada satu kesatuan dan persatuan bangsa ditengah perbedaan dalam satu kekuatan bangsa. ${ }^{4}$

Tujuan artikel ini ditulis agar setiap orang dapat menyadari betapa pentingnya toleransi agama itu dibangun sehingga dapat diekspresikan sebagai sikap yang saling menghargai dan menghormati keyakinan orang lain. Sehingga dari toleransi agama setiap orang dapat menghindari konflik dibangsa Indonesia yang didalamnya memiliki beberapa agama yang berbeda, maka hal ini akan menciptakan satu kesatuan bangsa untuk tetap hidup dalam kebersamaan dengan damai dan rukun dengan mengakui bahwa kehidupan manusia membutuhkan manusia lain walaupun itu pada perbedaan keyakinan sekalipun. Tulisan ini juga bermaksud untuk membangun sikap iman keKristenan untuk melihat toleransi agama seabagai pendekatan misi untuk membawa damai kasih Allah dalam perwujudan interaksi sosial.

\section{Metode Penelitian}

Artikel ini menggunakan pendekatan kualitatif dengan metode deskriptif-analisis dengan menggunakan beberapa sumber pustaka buku dan jurnal. ${ }^{5}$ Mengenai toleransi beragama sebagai pendekatan misi Kristen di Indonesia. Tujuan dari menggunakan metode ini ialah untuk menggambarkan, meringkaskan berbagai kondisi, berbagai situasi, berbagai variabel yang timbul dalam masyarakat yang menjadi objek penelitian, kemudian menarik ke permukaan sebagai suatu ciri atau gambaran tentang kondisi, situasi atau variabel tertentu. Pemahaman metode deskriptif yang penulis maksudkan ialah penelitian tentang toleransi beragama sebagai pendekatan misi Kristen di Indonesia.

\section{Hasil dan Pembahasan}

\section{Sikap Toleransi Agama di Indonesia}

"Toleransi" merupakan sikap toleran, ${ }^{6}$ sikap bertenggang rasa,7 kelapangan dada, kerukunan, keluasan pikiran, ${ }^{8}$ bersikap menegakan pendirian/pendapat orang lain yang berbeda dengan pendirian sendiri. ${ }^{9}$ Menurut kamus besar bahasa Indonesia sikap toleran merupakan sikap menghargai, membiarkan, memperbolehkan pendirian, pendapat pandangan, kepercayaan, kebiasaan, kelakuan yang berbeda atau bertentangan dengan pendirian sendiri. ${ }^{10}$ Maka toleransi yang dimaksud penulis dalam penulisan ini adalah wujud dari sejarah masyarakat Indonesia yang terlahir dari perbedaan suku, budaya, bahasa dan agama, kemudian didorong dengan sikap pada ajaran agama.11

Bangsa Indonesia yang terdiri atas berbagai suku bangsa, ras agama dan budaya merupakan masyarakat yang heterogen. Jika di antara masyarakat ada yang merasa lebih tinggi dibandingkan dengan yang lain, hal ini mudah memicu konflik yang dapat 2006), 414.

${ }^{4}$ Stervri. I. Lumintang, Theologia Dan Misiologia Reformed (Malang: Departemen Literatur PPII,

5 Sonny Eli Zaluchu, "Strategi Penelitian Kualitatif Dan Kuantitatif Di Dalam Penelitian Agama," Evangelikal: Jurnal Teologi Injili dan Pembinaan Warga Jemaat 4, no. 1 (2020): 28-38.

6 Kamus Besar Bahasa Indonesia Edisi III (Jakarta: Balai Pustaka, 2001), 1204.

${ }^{7}$ M. Dahlan Y. Al-Barry, Kamus Induk Istilah Ilmiah (Surabaya: Target Press, 2003$), 777$.

${ }^{8}$ Harimurti Kridalasana, Kamus Sinonim Bahasa Indonesia (Flores: Nusa Inda, 1977), 196.

${ }^{9}$ Cormentyna Sitannggang, Kamus Pelajar (Bandung: Remaja Rosdakarya, 2003), 782.

${ }^{10}$ Kamus Besar Bahasa Indonesia Edisi III, 1204.

${ }^{11}$ Weinata Sairin, Kerukunan Umat Beragama (Jakarta: BPK Gunung Mulia, 2006), 6. 
mengakibatkan munculnya masalah sosial.12 Hal ini dapat mengakibatkan terjadinya perubahan-perubahan dalam masyarakat terutama dalam rangka mencapai suatu integrasi yang dapat diterima oleh berbagai pihak.13 Oleh karena itu toleransi agama merupakan keunikan dan kekayaan tersendiri bagi hidup berbangsa dan bertanah air, di samping itu toleransi agama merupakan tantangan sekaligus ancaman integrasi bangsa yang dapat memicuh perpecahan bangsa. ${ }^{14}$ Maka perlu juga adanya kekuatan hukum untuk menjamin kerukunan Umat beragama, Pemerintah Indonesia memiliki beberapa peraturan sebagai landasan hukum Kerukunan beragama di Indonesia sebagai berikut: 1) Landasan Idiil, yaitu Pancasila sila pertama Ketuhanan yang Maha Esa; 2) Landasan Konstitusional, yaitu Undang-undang 1945, Pasal 29 ayat 1 "Negara berdasarkan Ketuhanan Yang Maha Esa"; dan Pasal 29 ayat 2 "Negara menjamin kemerdekaan tiap-tiap penduduk untuk memeluk agamanya masing-masing dan untuk beribadah menurut agamanya dan kepercayaannya itu"; 3) Landasan Strategis, yaitu Ketetapan MPR No.IV tahun 1999 tentang Garis-garis Besar Haluan Negara (GBHN) dan Program Pembangunan Nasional (PROPENAS) tahun 2000, dinyatakan bahwa sasaran pembangunan bidang agama adalah terciptanya suasana kehidupan beragama dan kepercayaan terhadap Tuhan yang Maha Esa, yang penuh keimanan dan ketaqwaan penuh terhadap Tuhan Yang Maha Esa, secara bersama-sama makin memperkuat landasan spiritual, moral dan etika bagi pembangunan nasional, yang tercermin dalam suasana kehidupan yang harmonis, serta dalam kukuhnya persatuan dan kesatuan bangsa selaras dengan penghayatan dan pengamalan Pancasila. 4) Landasan Operasional: Penetapan Presiden No.1/PNPS/1965 tentang Pencegahan Penyalagunaan dan/atau Penodaan Agama yang kemudian dikukuhkan pada Orde Baru menjadi UU No.1/PNPS/1965, Keputusan bersama Menteri Dalam Negeri dan Menteri Agama RI. No. 01/Ber/Mdn/1969 tentang pelaksanaan aparat pemerintah yang menjamin ketertiban dan kelancaran pelaksanaan dan pengembangan ibadah pemeluk agama oleh pemeluknya, SK. Menteri Agama dan Menteri Dalam Negeri RI. No. 01/1979 tentang tata cara pelaksanaan penyiaran agama dan bantuan luar negeri kepada lembaga-lembaga keagamaan swasta di Indonesia dan Surat edaran Menteri Agama RI. No.MA/432.1981 tentang penyelenggaraan peringatan hari besar keagamaan. ${ }^{15}$

Dengan demikian penulis menyimpulkan, toleransi beragama memiliki landasan hukum sebagai wujud usaha mencapai kerukunan antar umat beragama yang dikenal dengan landasan idiil, landasan konstitusional, landasan strategis dan landasan operasional. ${ }^{16}$

\section{Toleransi Beragama Dalam Ajaran Agama Lainnya}

Ajaran agama Islam, Teladan luhur Nabi Muhammad terhadap kaum ahl adzadzimmi, menjadi bagian dari kisah toleransi beragama dalam Islam. ${ }^{17} \mathrm{Hal}$ ini menurut penulis hanya sebagai wujud dari pendekatan sosial dalam konteks Indonesia. Maka seharusnya toleransi dalam Islam memiliki posisi yang penting, oleh karena dalam konteks Indonesia agama Islam yang mayoritas, maka seharusnya umat Islam dapat memberikan Yaqub."

${ }^{12}$ Anggraeni and Suhartinah, “Toleransi Antar Umat Beragama Perspektif KH. Ali Mustafa 2007), 13.

${ }^{13}$ Bagja Waluya, Sosiologi: Menyelami Fenomena Di Masyarakat (Bandung: PT Setia Purna Inves,

${ }^{14}$ Casram, "Membangun Sikap Toleransi Beragama Dalam Masyarakat Plural."

${ }^{15}$ Eka Purwaningsih, Pentingnya Hidup Rukun (Jakarta: PT Balai Pustaka, 2016), 6-7. Yaqub."

${ }^{16}$ Anggraeni and Suhartinah, "Toleransi Antar Umat Beragama Perspektif KH. Ali Mustafa

17 Bambang Noorsena, Jangan Sebut Saudaramu Kafir (Malang: Institute for Syriac Christian Studies (ISCS), 2008), 27. 
kebebasan pada agama lain untuk hidup dan berkembang bukan sebaliknya menindas minoritas agama lain. Menjadi perhatian penting dalam ajaran toleransi agama, kitab suci Alquran. ${ }^{18}$ Khususnya Al-Qur'an: Al-Hujarat 49:13 yang menetapkan persamaan yang mutlak antara sesama manusia. Jelaslah dalam kesadaran inilah, umat Islam seharusnya memiliki sikap toleran untuk memberikan kebebasan pada agama lain yang menciptakan kedamaiaan dan kerukunan agama. ${ }^{19}$

Dalam ajaran agama Hindu, wujud konkret dari semangat toleransi secara intrinsik tersurat dalam empat jalan yang ditawarkan dalam Bhagavadgita/Bagawadgita yaitu Jnanan Marga, Bhakti marga, Karma Marga, Yoga Marga. ${ }^{20}$ Demikian juga disebutkan oleh James ada empat jalan yang menuntun pada persamaan dalam berbagai aspek kehidupan masyarakat, yang dikenal dengan "the path of action" atau karma marga, "the path of devotion" atau bhakti marga, "the path of union" atau yoga marga, dan "the path of knowing" atau jhana marga. Dari empat jalan ini, jalan kedua dan kempat adalah yang paling prinsip. ${ }^{21}$ Namun hal ini juga tidak berarti dipahami sebagai sikap toleran, oleh karena ajaran hindu pun memeliki capaian tersendiri, maka perlu dimaknai lagi ajaran hindu untuk dapat memiliki sikap toleransi agama yang utuh, seperti pada ajaran Yoga yang berasal dari bahasa Sansekerta "Yuj"yang artinya menghubungkan atau hubungan yakni hubungan yang harmoni dengan objek. Kesadaran ajaran yoga ini memungkinkan orang untuk dapat bersikap toleran dengan agama lain, sebagai wujud pendekatan dari interaksi perbuatan sosial. ${ }^{22}$

Dalam ajaran Buddha, mengenai kerukunan umat beragama berasal dari agama Sang Buddha. Sikap toleran Sang Buddha diceritakan dalam percakapan beliau dengan Upali, seorang penganut aliran Jaina, tentang hukum karma. Dalam percakapan itu Upali meminta agar Sang Buddha dapat menerimanya sebagai murid. Sampai tiga kali Sang Buddha menolak permintaan itu. Akhirnya Buddha menerima Upali sebagai penganutnya dan Buddha mengatakan "kami menerima Anda sebagai umatku, sebagai muridku, dengan harapan Anda tetap menghargai agamamu dan menghormati bekas gurumu itu serta membantunya." 23 Kerukunan hidup umat beragama Buddha diwarnai sifat-sifat paramita atau sifat-sifat luhur. Umat Buddha beriman kepada Sanghyang Adi Buddha dan berusaha untuk memiliki sifat-sifat ketuhanan dan mengembangkan sifat-sifat itu di dalam diri mereka sendiri.24 Jika dipahami dari ajaran Budha ini maka dapat diartikan dalam hubungannya dengan toleran agama harus adanya sikap yang utuh, oleh karena ajaran ini hanya berpusat secara pengejaran tidak berwujud pada sikap toleran, maka perlu ada keseimbangan ajaran yang berdampak pada sikap terhadap agama lain untuk saling menerima perbedaan.

Agama Konghucu, mengajarkan pemeluknya untuk hidup rukun dengan pemeluk agama lainnya. Lima sifat yang mulia atau wu chang merupakan konsep ajaran yang mengajarkan umatnya untuk dapat hidup harmonis dengan sesamanya. Sifat Pertama, re/jin, memiliki arti cinta kasih, tabu diri, halus budi pekerti, tenggang rasa, serta dapat menyelami perasaan orang lain. Sifat Kedua, $i / g i$, yaitu rasa solidaritas, senasib, sepenanggungan dan

${ }^{18}$ Djohan Effendi, Merayakan Kebebasan Beragama (Jakarta: Indonesian Conference on Religion and Peace, 2009), 408.

${ }^{19}$ Suryan Suryan, "Toleransi Antarumat Beragama: Perspektif Islam," Jurnal Ushuluddin 23, no. 2 (2017): 185-200.

20 Jimmy B. Oentoro, Indoneisa Satu, Indonesia Beda, Indonesia Bisa (Jakarta: PT Gramedia Pustaka Utama, 2010), 116.

${ }^{21}$ Michael D. A. James, Happiness and The Art of Being (India: Create Space, 2012), 331.

22 Ida Bagus Putu Eka Suadnyana, "Ajaran Agama Hindu Dalam Cerita Batur Taskara," Sanjiwani: Jurnal Filsafat 11, no. 2 (2020): 232-244.

23 Andreas A. Yewangoe, Agama Dan Kerukunan (Jakarta: BPK Gunung Mulia, 2009 ), 57.

${ }^{24}$ Yusuf A. Puar, Panca Agama Di Indonesia (Jakarta: Pusaka Antara PT, 1977), 137. 
rasa membela kebenaran. Sifat Ketiga, li atau lee, yaitu sikap sopan santun, tata krama dan budi pekerti. Sifat Keempat, ce atau ti, yaitu sikap bijaksana, rasa pengertian, dan kearifan. Dan sifat terakhir dari wu chang disebut dengan sin yang memiliki arti kepercayaan, rasa untuk dapat dipercaya oleh orang lain serta dapat memegang janji dan menepatinya. ${ }^{25}$ Bahkan salah satu pokok ajaran Konghucu adalah tiong si atau satya kepada Firman Thian dan tepasalira atau berempati kepada sesama manusia. Pokok ajaran tersebut telah mengatur hubungan manusia dengan Thian di satu sisi dan di sisi lain mengatur hubungan antar manusia. Ditegaskan dalam Lun Gi dan Bingcu, bahwa manusia harus mampu menjaga kelestarian alam dan segala isinya. Manusia wajib bersahabat dan hidup penuh harmoni tidak saja di antara sesamanya, namun juga dengan alam dan segala isinya. ${ }^{26}$ Pengajaran dari agama konghuchu ini dapat diartikan sebagai bentuk sifat dari perasaan bukan satu tindakan nyata dalam sikap dari dasar ajaran itu sendiri, maka hal ini tidak dapat katakana juga sebagai satu sikap tindakan secara nyata sebagai toleran agama.

Dengan demikian penulis memahami dari bebarapa penjelasan di atas terhadap ajaran dari agama Islam, Hindu, Budha dan konghuchu, bahwa setiap agama memiliki dasar pengajaran agama yang kuat dan mutlak yang dapat memungkinkan untuk dapat mengatakan bahwa agama tertentu saja yang benar dan agama lain salah, hal ini tentunya bisa saja berpeluang untuk dapat menciptakan suasana konflik yang mengakibatkan perpecahan bangsa. Maka seharusnya keyakinan agama apapun itu tentunya dapat memberikan tanggung jawab pengajaran dari masing-masig agama yang berdampak pada sikap toleran yang kuat, sehingga hal ini dapat dijadikan wadah untuk menyamakan perspekti sikap dari beberapa keyakinan agama yang berbeda pada perwujudan interaksi sosial tanpa menganggap keyakinan agama tertentu yang benar, tetapi keyakinan yang ada mampu menerima perbedaan iman orang lain sebagai wujud dari pengajaran agama. Maka tepatlah toleransi agama itu dibangun di Indonesia sehingga hal ini dapat juga memungkinkan sebagai metode pendekatan misi.

\section{Peran Pancasila Dalam Toleransi Beragama}

Peran pancasila dalam toleransi agama memberikan alasan yang kuat untuk membuka ketidaksadaran selama ini yang berdampak pada konfilik maka dari itu peran pancasila akan memberi pemahaman yang luas untuk memahami arti dari toleransi agama dalam konteks Indonesia, dalam perubahan pemaham yang salah akan sikap toleransi yang dapat saja berdampak pada konflik perpecahan bangsa. Sehingga sebagai umat beragama di Indonesia, Islam, Kristen Protestan, Katolik, Hindu, Buddha dan Konghucu memiliki perbedaan ritus dalam tiap kepercayaan namun disatukan oleh nilai sila pertama Ketuhanan yang Maha Esa. Dengan demikian, penghayatan kepada Tuhan yang Maha Esa dalam sila pertama tepat sebagai pemersatu bangsa. Untuk itu toleransi beragama, boleh dibangun di atas kebenaran yang digali dari nilai-nilai Pancasila. ${ }^{27}$ Melalui proses yang perumusan Undang-undang Dasar sampai pada disahkannya Undang-undang Dasar 1945, maka rumusan Pancasila adalah sebagai berikut:

1. Ketuhanan Yang Maha Esa

2. Kemanusiaan yang adil dan beradab

3. Persatuan Indonesia

${ }^{25}$ A. Rani Usman, Etnis Cina Perantauan Di Aceh (Jakarta: Yayasan Pusaka Obor Indonesia, 2009), 86.

${ }^{26}$ Budi S. Tanuwibowo, Agama Dan Negara, Perspektif Islam, Katolik, Hindu, Buddha, Konghucu, Protestan (Yogyakarta: Institut DIAN/Interfidei, 2002), 92.

${ }^{27}$ Ibnu Rusydi and Siti Zolehah, "Makna Kerukunan Antar Umat Beragama Dalam Konteks Keislaman Dan Keindonesian," Al-Afkar, Journal For Islamic Studies 1, no. 1, January (2018): 170-181. 
4. Kerakyatan yang dipimpin oleh hikmat kebijaksanaan dalam permusyawaratan perwakilan

5. Keadilan sosial bagi seluruh rakyat Indonesia. 28

Melewati sejarah panjang, mulai dari masa kerajaan-kerajaan di Indonesia, penjajahan Belanda selama berabad-abad, empat puluh bulan di bawah pemerintahan penduduk Jepang, sampailah bangsa Indonesia ke zaman kemerdekaan. Usul Ir. Soekarno pada sidang pertama BPUPKI hari terakhir tanggal 1 Juni 1945 yang secara resmi menggunakan istilah Pancasila yang secara literal memiliki arti lima dasar, maka Pancasila pun sah sebagai dasar negara. ${ }^{29}$ Berdasarkan latar belakang histori, sosial, budaya dan kenyataan sehari-hari masyarakat Indonesia, maka Pancasila adalah pilihan terbaik bagi bangsa Indonesia. ${ }^{30}$ Pancasila sebagai ideologi dalam perkembangannya bersifat aktual, dinamis dan senantiasa menyesuaikan dengan perkembangan zaman, ilmu pengetahuan dan teknologi, serta dinamika perkembangan sosial masyarakat Indonesia. ${ }^{31}$ Sebagai ideologi negara Pancasila memiliki cakupan yang lebih luas dari pada sebagai filsafat negara. Pancasila sebagai ideologi negara tidak hanya membentuk hukum tetapi juga berbentuk norma-norma lain yang harus dijadikan pedoman warga negara. ${ }^{32}$ Pancasila menjadi dasar tata hukum Indonesia dalam kehidupan bermasyarakat ada beberapa norma yang perlu ditaati, yaitu norma agama, norma kesusilaan dan norma kesopanan sehingga norma tersebutlah yang mendasari suatu masyarakat. ${ }^{33}$

Pusat Studi Pancasila menyebutkan: Pancasila berada dalam dua kedudukan. Sebagai Cita Hukum (Rechtsidee), Pancasila berada dalam Tata Hukum Indonesia namun terletak di luar sistem norma hukum. Dan dalam kedudukan yang demikian itu Pancasila berfungsi secara kostitutif dan regulatif norma-norma yang ada dalam sistem norma hukum. Selanjutnya, sebagi norma yang tertinggi dalam pembukaan UUD 1945, Pancasila merupakan Norma Dasar (ground norm), yang menciptakan semua norma- norma yang lebih rendah dalam sistem norma hukum tersebut, serta menentukan berlaku tidaknya normanorma dimaksud. ${ }^{34}$ Pancasila dalam hubungan antar umat beragama adalah baik jika dijalani kalau semuanya bermuara pada tujuan untuk mengamalkan sila-sila dari Pancasila.

Dengan Pancasila umat beragama juga akan mempunyai dasar yang kuat untuk menentang setiap usaha pemecah belah (devide et impera) antar umat beragama di Indonesia. ${ }^{35}$ Sila Ketuhanan yang Maha Esa tidak lain berdasarkan realitas kemajemukan agama-agama di Indonesia. ${ }^{36}$ Pancasila menjamin kebebasan setiap agama dalam menjalankan ajaran kepercayaan, tanpa campur tangan pemerintah. Namun demikian, di dalam negara Pancasila, kebebasan tidak boleh diartikan kebebasan tanpa batas. Kebebasan 723-735.

${ }^{28}$ Pranoto Iskandar, "The Pancasila Delusion," Journal of Contemporary Asia 46, no. 4 (2016):

29 Pandji Setijo, Pendidikan Pancasila Perspektif Perjuangan Bangsa (Jakarta: Grasindo, 2012), 10.

30 Bambang Ruseno Utomo, Hidup Bersama Di Bumi Pancasila "Sebuah Tinjauan Hubungan Islam Dan Kristen Di Indonesia (Malang: Pusat Studi Agama dan kebudayaan, 1993), 22-27.

${ }^{31}$ Aim Abdulkarim, Pendidikan Kewarganegaraan "Membangun Warga Negara Yang Demokratis (Jakarta: Grafindo Media Pratama, 2015), 19.

32 P.J. Suwarno, Pancasila Budaya Bangsa Indonesia (Yogyakarta: Kansius, 1993), 111.

33 Suparman, Pancasila (Jakarta: PT Balai Pustaka (Persero), 2010), 7.

34 Pusat Studi Pancasila, Membangun Kedaulatan Bangsa Berdasarkan Nilai-Nilai Pancasila: Pemberdayaan Masyarakat Dalam Kawasan Terluar, Terdepan Dan Tertinggal (3T) (Yogyakarta: Universitas Gadjah Mada, 2015), 161.

35 Olaf Herbert Schumann, Agama Dalam Dialog: Pencerahan, Pendamaian Dan Masa Depan, (Jakarta: BPK Gunung Mulia, 2018), 90.

${ }^{36}$ Dkk Andreas Kristianto, Aan Anshori, Yoses Rezon S., Jalan Lain Perdamaian Refleksi Kolektif Para Penggiat Keragaman (Jakarta: Grafika Kreasindo, 2016), 8. 
harus diletakkan di dalam kerangka dan batas kesatuan serta persatuan bangsa, yang menjadi salah satu bentuk utama dari jiwa Pancasila. Karena itu, prinsip kebebasan beragama bukanlah prinsip satu-satunya. Prinsip tersebut berdampingan dan bertalian erat dengan prinsip kerukunan beragama, atau kerukunan umat beragama. ${ }^{37}$ Pancasila menjadi dasar hidup bersama agama-agama yang berbeda di Indonesia. Karena itu, Pancasila menjadi dasar toleransi agama. ${ }^{38}$ Toleransi beragama sangat berarti apabila masing-masing agama terus menempatkan Pancasila sebagai dasar hidup berbangsa dan bernegara. Dari uraian di atas dapat disimpulkan bahwa Pancasila sebagai dasar negara sangat berperan dalam mempersatukan umat beragama di Indonesia dan menjadi dasar toleransi beragama di Indonesia.

\section{Toleransi Beragama Dalam Perspektif Kristen Perjanjian Lama}

Perjanjian lama secara konsisten menegaskan bahwa hanya Allah yang kekal dan Allah secara bebas menciptakan alam semesta serta segala sesuatu yang ada di dalamnya. (Kej. 1-2; Yes. 40: 28; 42:5; 45:18). Dengan demikian, ada pembedaan ontologis fundamental antara Allah Pencipta yang kekal dengan ciptaan-Nya. Di puncak ciptaan Allah ada manusia, yang diciptakan menurut gambar dan rupa Allah (Kej. 1:26-27;5:1-3). ${ }^{39}$ Inilah dasar toleransi dalam konsep penciptaan, bahwa semua ciptaan Allah berhak menikmati hidup dari sesama ciptaan allah yang lain. Secara khusus, semua ciptaan allah yang lain, adalah diciptakan oleh Allah demi untuk melayani kebutuhan manusia (Kej.1:28). Tentu, ciptaan lain tidak hanya menjadi pelayan bagi manusia secara sepihak, melainkan, kepada manusia yang dilayani, dituntut tanggungjawab memelihara ciptaan yang lain, supaya tercipta keharmonisan antara semua ciptaan. Tugas manusia atas ciptaan lain, adalah menaklukkan, menguasai dan menata ciptaan yang lain. Lebih dari pada itu, Pencipta memanggil manusia untuk hidup saling melayani dengan sesama manusia, tanpa melihat latar belakang agama. Konsep penciptaan seperti ini, merupakan dasar sikap toleransi orang Kristen bagi sesamanya yang beragama lain.40 Maka dapat disimpulkan bahwa konsep penciptaan sebagai dasar toleransi karena semua ciptaan memiliki hak untuk menikmati hidup di dunia yang telah Allah ciptakan.

Kerukunan dan kedamaiaan merupakan perintah dalam kehendak Allah bagi umatNya untuk mengalami berkat Allah (Mazmur 133:1-3). Kasih Allah diwujudkan dalam sikap yang nyata seperti yang diungkapkan oleh pemazmur adalah Allah yang baik bagi semua orang. Ini membuktikan bahwa Allah mengasihi semua orang. Wahyu umum merupakan bukti nyata Allah ada bagi semua orang, ketika Tuhan memberikan hujan maka itu bukan hanya dinikmati oleh orang Kristen saja tapi semua orang dengan agama apapun dapat menikmati hujan yang Allah berikan. Alkitab dalam ajarannya memposisikan manusia sebagai sesama yang harus dipandang sebagai mahkluk ciptaan Allah. Maka dengan demikian, Allah sebagai sumber iman kekristenan dalam prkatik hidup pelayanan dan pengajaran, dalam wujud toleransi bahwa orang percaya dituntut untuk membawa damai, maka hal ini akan dipahami sebagai batasan untuk dapat melihat menerima perbedaan dengan sikap menghargai dan menghormati agama lain, namun tidak mengkompromikan

4.

37 Victor I. Tanya, Pluralisme Agama Dan Problema Sosial (Jakarta: PT. Pustaka Cidesindo, 1998),

38 Stevri I. Lumintang, Theologia Abu-Abu: Pluralisme Agama, Edisi Revisi (Malang: Gandum Mas, 2009), 273.

${ }^{39}$ Harold Netland, Encountering: Religious Pluralism. Tantangan Bagi Iman Dan Misi Kristen (Malang: Literatur SAAT, 2015), 342.

${ }^{40}$ Lumintang, Theologia Abu-Abu: Pluralisme Agama, Edisi Revisi, 281. 
jati diri Kekristenan yang berakar pada kebenaran-kebenaran esensial dari Alkitab. ${ }^{41}$ Dengan demikian penyataan diri Allah ke dunia untuk dapat berhubungan dengan manusia merupakan bentuk toleransi Allah kepada manusia sekaligus menjadi contoh agar orang percaya dapat menyatakan kebenaran berdasarkan nilai-nilai Kekristenan dalam tindakan kasih untuk membawa damai kepada sesama dalam konteks toleransi agama.

\section{Perjanjian Baru}

Kitab Perjanjian Baru juga memberikan wujud kehendak Allah untuk dipahami sebagai sikap hidup bermasyarakat dalam toleransi agama yang dapat diwujudkan nyatakan sebagai Allah yang menyatakan diri-Nya, yaitu membuat Ia dikenal oleh manusia. Tuhan dalam menyatakan diri-Nya supaya manusia dapat berhubungan langsung dengan Dia. Allah menyatakan diri-Nya melalui kedatangan Yesus Kristus ke dunia. Allah telah menyatakan diri-Nya melalui kedatangan Yesus, orang Nazaret, dan bahwa Roh Kudus menyatakan juga kepada manusia, bahwa Yesus adalah Kebenaran yang dari Allah. Maka dasar toleransi Kristen melalui penyataan diri Allah kepada manusia merupakan tindakan toleransi Allah atas manusia ciptaan-Nya. Tindakan ini menyatakan kerelaan Allah membatasi diri-Nya demi membangun komunikasi dengan umat-Nya.

Pengajaran yang jelas bagi kekristenan melalui keteladanan Yesus dalam sikap toleransi agama. Hal ini tergambarkan pada kasih Allah kepada umatNya tanpa melihat perbedaan yang terletak pada diri manusia. Allah menunjukkan kasih-Nya kepada manusia berdosa, oleh karena Kristus telah mati untuk menebus manusia dari dosa (Rm. 5:7-8). Lumintang menjelaskan bahwa toleransi yang Alkitabiah tentu dianalogikan dengan sikap Allah kepada manusia berdosa, bahwa Allah toleran kepada manusia karena kasih-Nya, namun Allah intoleran terhadap dosa manusia. ${ }^{42}$ Demikian juga dengan setiap orang percaya perlu menerima orang lain sebagai bukti mengasihi sesama namun bukan berarti menerima kepercayaannya, maka daripada itu penulis menyimpulkan bahwa kasih Allah sebagai dasar hidup bertoleransi orang-orang percaya dan setiap orang percaya yang tentunya akan menerima dan menghargai orang lain dengan perbadaan keyakinan bahkan dapat memberitakan kabar keselamatan sebagai bukti mengasihi Allah dan sesama.

\section{Misi Kristen}

Istilah Misi berasal dari bahasa Latin missio yaitu pengutusan. Dalam bahasa Inggris, Jerman dan Perancis mission. Dalam bahasa Belanda missie, dalam Gereja Protestan memakai istilah zending. Dalam bahasa Inggris bentuk tunggal mission berarti karya Allah (God's mission) atau tugas yang diberikan oleh Tuhan kepada manusia (our mission), sedangkan bentuk jamak missions menandakan kenyataan pelakasanaannya. ${ }^{43}$ Bahasa Latin missio yang diangkat dari kata dasar mittere yang berkaitan dengan kata missum yang artinya to send yaitu mengutus atau mengirim, act of sending, being or delegated by authority/person sent, etc." 44 Lumintang menjelaskan bahwa misi adalah umat Allah yang sengaja melintas tapal batas dari gereja ke luar gereja, dari iman kepada mereka yang belum beriman untuk memprokamirkan dengan perkataan dan perbuatan, kedatangan Kerajaan Allah yang dinyatakan dalam Yesus Kristus, melalui partisipasi gereja dalam misi Allah, yaitu pendamaian manusia yang telah didamaikan ke dalam gereja yaitu mereka yang bertobat

\footnotetext{
41 Ibid., 280.

42 Ibid., 284.

43 Arie de Kuiper, Misiologia (Jakarta: BPK Gunung Mulia, 2010), 8-10.

${ }^{44}$ Dr. Yakob Tomatala, Teologi Misi (Jakarta: YT Leadership Foundation, 2003), 6.
} 
dan beriman kepada Yesus Kristus melalui karya Roh Kudus supaya dunia ditransformasi sebagai tanda Kerajaan Yesus Kristus yang akan datang. ${ }^{45}$

Misi Kristen adalah kegiatan apostolik dan pelayanan yang bersumber dan berasal dari penyataan Kristen sebagaimana disaksikan oleh Alkitab. 46 Hakikat utama misi Kristen adalah mewartakan dengan setia kebenaran dalam Yesus Kristus. Misi Kristen dilakukan dengan sikap solidaritas mendalam terhadap sejumlah besar problem kemanusiaan, moral, sosial yang terjadi di kalangan umat beragama dari semua agama. Kemudian, berusaha menunjukkan bahwa keinginan untuk memperkenalkan kebenaran dalam Yesus Kristus dan bersamaan dengan itu, perlunya peningkatan pengertian dan pemahaman yang tulus tentang agama lain. Misi Kristen harus selalu terbuka bagi setiap kemungkinan terciptanya hubungan antar agama dan kerjasama dalam meringankan penderitaan yang dialami umat manusia dan melayani berbagai kebutuhan dan masalah-masalah dunia dalam perwujudan interaksi sosial dengan melihat pada kebetuhan manusia tanpa melihat perbedaan. ${ }^{47}$

Penginjilan adalah bagian dari misi. Penginjilan merupakan pemberitaan Kabar Baik tentang Yesus Kristus dengan tujuan supaya orang mengenal akan Kristus dan mengerti tentang kabar baik itu. ${ }^{48}$ Seperti yang diungkapkan oleh Putranto, "Pada hakikatnya misi adalah usaha untuk menyampaikan Injil kepada manusia yang masih berada di luar keselamatan karena belum mendengar dan belum menerima Injil." 49 Karena itu, tanpa merusak semangat toleransi, pastinya penginjilan dalam pendekatan-pendekatan manusiawi dan tanpa memanipulasi segala cara untuk mendapatkan hasil. ${ }^{50}$ Penginjilan manipulatif, yang bernafaskan paksaan, hipnotis, rayuan, dan sebagainya, sesungguhnya bertentangan dengan hakikat Injil yang berkuasa dari Injil itu sendiri (Rm.1:16-17).

Lumintang menyatakan, penginjilan akan lahir dari Injil itu sendiri melalui orang yang telah mengalami kuasa Injil, telah menjadi percaya kepada Injil, ia tidak akan mungkin berdiam diri, melainkan ia akan menyaksikan Injil. Karena itu, orang yang tidak memberitakan Injil, dan yang melarang orang untuk menginjili, atau yang telah merubah arti penginjilan itu menjadi dialog demi mencari kebenaran dan membangun persekutuan dengan pemeluk agama lain pastilah orang yang belum mengalami kuasa Injil itu sendiri. ${ }^{51}$ Penginjilan bukanlah tindakan bagaimana orang percaya mengundang orang datang, melainkan orang percaya diutus pergi memberitakan Injil. Karena jika orang percaya tidak memberitakan Injil Kerajaan Surga, maka tugas gereja tidak mungkin mengalami terobosan selamannya. ${ }^{52}$ Dengan demikian bahwa misi Kristen bukanlah usaha kristenisasi namun pada hakikatnya misi Kristen merupakan pengutusan orang percaya untuk memberitakan karya Allah menyelamatkan manusia melalui pengorbanan Yesus Kristus yang datang ke dunia. $^{53}$

361.

${ }^{45}$ Stevri I. Lumintang, Teologi \& Misiologia Reformed (Batu: Departemen Literatur YPPII, 2006),

${ }^{46}$ Nicolas J Woly, Perjumpaan Di Serambi Iman: Suatu Studi Tentang Pandangan Para Teolog Muslim Dan Kristen Mengenai Hubungan Antaragama (Jakarta: BPK Gunung Mulia, 2010), 307.

${ }^{47}$ Ibid., 308.

${ }^{48}$ C. Peter Wagner, Strategi Perkembangan Gereja (Malang: Gandum Mas, 2007), 6.

${ }^{49}$ Bambang Eko Putranto, Misi Kristen (Yogyakarta: ANDI, 2007), 6.

50 Stervri. I Lumintang, Re-Indonesianisasi Bangsa (Batu: Petrus Octavianus Institute, 2009), 629.

${ }^{51}$ Lumintang, Theologia Abu-Abu: Pluralisme Agama, Edisi Revisi, 285.

52 Stephen Tong, Theologi Penginjilan (Jakarta: LRII, 1988), 53.

53 Daniel Syafaat Siahaan, "Ketika Aku Dan Kamu Menjadi Kita: Dialog Misi Penginjilan Kristen Dengan Dakwah Islam Menggunakan Pendekatan Teologi Interkultural Dalam Konteks Indonesia," GEMA TEOLOGIKA: Jurnal Teologi Kontekstual dan Filsafat Keilahian 2, no. 1 (2017): 41-54. 
Pendekatan adalah proses atau cara atau perbuatan mendekati hendak berdamai atau bersahabat atau lainnya. ${ }^{54}$ Di dalam menjalankan misi diperlukan suatu strategi yang tepat untuk pendekatan. Pendekatan misi dapat dilakukan melalui sosial, politik, budaya, ekonomi, dan agama. Untuk dapat menjangkau jiwa atau untuk mendekati seseorang yang belum percaya kepada Yesus Kristus pendekatan misi harus dilakukan dengan membangun hubungan yang baik dengan orang lain atas dasar kasih. Kasih merupakan dasar sikap toleransi orang percaya. Oleh sebab itu sikap toleran kepada umat yang beragama lain merupakan satu cara untuk mempermudah dan menolong orang yang akan menjalankan misi Kristen di Indonesia.

\section{Implikasi}

Sebagaimana telah dijelaskan bahwa toleransi beragama merupakan hal yang sangat memungkinkan untuk melakukan pendekatan misi dalam tindakan kemanusiaan atau usaha interaksi sosial. Oleh sebab itu keKristenan perlu mengimplementasikan toleransi beragama dalam pelayanan misi kepada sesama umat Kristen dan umat yang berbeda agama. ${ }^{55}$ Setiap orang percaya dituntut untuk memberitakan Injil Kristus. ${ }^{56}$ Orang percaya atau gereja sebagai penerima mandat misi untuk melakukan Amanat Agung Kristus sampai ke unjung bumi. ${ }^{77}$ Sebab Amanat Agung yang diberitakan bertujuan membawa jiwa bagi Tuhan.58 Seperti misi yang dilakukan oleh Yesus Kristus sehingga masa kini memiliki tujuan supaya setiap orang mendengar Injil dapat menerima Yesus sebagai Tuhan dan juruselamat. Melalui kuasa Roh Kudus, orang percaya juga dimampukan untuk melengkapi agar dapat bersaksi bagi Kristus. Perubahan hidup itu harus berpusat kepada Allah yang ditunjukan pada sikap hidup yang taat kepada Allah yang tercermin dalam perbuatan baik dan benar yang bertumbuh dalam kebenaran Firman Tuhan yang berdampak pada orang lain yang berbeda keyakinan sekalipun.

\section{Kepada Sesama Umat Kristen}

Keharusan yang mendasar bagi kekristenan adalah menyadarai bahwa anugerah Allah melalui karya kasih Kristus diatas kayu salib memberikan kebebasan hukum dosa, dalam keselamatan yang kekal. Namun kesadaran ini tidak sepenuh dialami oleh semua orang percaya, oleh karena ada banyak orang Kristen yang tidak menjadi berkat. Maka perlu pelayanan misi kepada orang percaya atau gereja yang berdasar pada kebenaran firman Tuhan dengan tujuan membawa pada pertobatan yang sesungguhnya kepada Yesus yang berdampak pada pemberitaan Injil.

Tuhan Yesus mengajarkan serta menjadi teladan bagi orang percaya untuk mengasihi Tuhan dan sesama (Mat. 22:37-39). ${ }^{59}$ Oleh sebab itu, setiap orang percaya perlu membangun hubungan yang berlandaskan kasih dan menjadi teladan antar satu sama lain. Inilah yang perlu terimplementasikan dalam hubungan internal umat Kristen. Pelayanan misi tidak hanya terfokus pada orang-orang yang berbeda agama, tetapi kepada sesama orang percaya. Sebagaimana penyataan Allah, konsep pencipataan, konsep inkarnasi Tuhan

54 , Kamus Besar Bahasa Indonesia Edisi III, 246.

55 Siahaan, "Ketika Aku Dan Kamu Menjadi Kita: Dialog Misi Penginjilan Kristen Dengan Dakwah Islam Menggunakan Pendekatan Teologi Interkultural Dalam Konteks Indonesia."

56 J. I. Packer, Penginjilan Dan Kedaulatan Allah (Surabaya: Penerbit Momentum, 2003 ), 67.

57 Ibid., 78.

${ }^{58}$ David J. Bosch, Tranformasi Misi Kristen (Jakarta: BPK Gunung Mulia, 1998), 54.

${ }^{59}$ Alfons Renaldo Tampenawas, Erna Ngala, and Maria Taliwuna, "Teladan Tuhan Yesus Menurut Injil Matius Dan Implementasinya Bagi Guru Kristen Masa Kini," EDULEAD: Journal of Christian Education and Leadership 1, no. 2 (2020): 214-231. 
Yesus Kristus, dan kasih adalah dasar toleransi Kristen. Untuk itu, dalam penerapannya kepada sesama orang percaya, umat Tuhan bukan hanya teori perlunya ada tindakan nyata untuk saling mengasihi dengan menyatakan kebenaran kepada sesama orang percaya. Dalam hal ini, kekristenan masa kini seharusnya menerima perbedaan tanpa kompromi dengan dosa yang dilakukan sesamanya, melainkan tetap pada dasar iman yang teguh pada kebenaran firman Tuhan yang berdampak pada kasih Yesus dan sesama manusia.

\section{Kepada Umat Yang Berbeda Agama}

Sebagaimana pengertian dari toleransi beragama yaitu sikap menerima orang yang berbeda agama serta menghargai dan menghormati kepercayaan atau keyakinan iman orang lain. Sikap iman Kristen yang dibangun dalam konteks toleransi agama dimulai pada kesadaran panggilan bagi orang percaya untuk menghadirkan kasih kedamaiaan Allah kepada orang lainya yang memiliki keyakinan yang berbeda. Konsep toleransi agama justru itu dapat dicapai pada cara kita meyakini keyakinan ajaran secara pribadi kemudian direspon pada sikap menguasai emosional dengan menghindari klaim atas kebenaran, perspektif yang sempit, eksklusif yang dapat menimbulkan reaksi negatif yang dapat mengikibatkan konflik. Dengan demikian realita tindakan misi di tengah-tengah perbedaan keyakinan iman dapat menjadi tantangan sekaligus juga menjadi satu peluang yang baik untuk dapat memberitakan Injil.

Hal yang paling sederhana untuk dipahami sebagai pendekatan misi kepada orang yang belum percaya yaitu perlu menjalin hubungan yang baik dalam akomodasi interaksi sosial. Maka daripada itulah, peluang toleransi beragama perlu diterapkan agar mereka terbuka untuk mendengarkan kabar Keselamatan yang telah Allah kerjakan melalui pengorbanan Yesus Kristus. Ada beberapa hal yang perlu diperhatikan dalam penerapannya: konsep keyakinan yang mutlak secara internal. Pertama, kesadaran bahwa Allah menciptakan segala sesuatu untuk dinikmani bersama bukan hanya dengan sesama umat Kristen namun dengan umat yang berbeda agama. Kedua, sikap menerima orang yang berbeda agama namun tidak kompromi dengan ajaran yang menyimpang dari dasar kebenaran dalam kekristenan. Ketiga, kasih Allah sebagai dasar hidup bertoleransi orangorang percaya. Setiap orang percaya yang memiliki kasih tentunya akan menerima dan menghargai orang lain bahkan tanpa rasa takut akan memberitakan kabar keselamatan sebagai bukti mengasihi Allah dan sesamanya. Keempat, sikap keteladanan Yesus menjadi contoh keteladanan hidup orang percaya untuk menjadi berkat bagi mereka yang belum percaya Yesus tanpa ada paksaam keyakinan kepada orang lain. Maka demikian sikap dari konsep toleransi beragama dapat dijadikan sebagai pendekatan misi dalam wujud interkasi sosial dengan fasilitas dialog agama-agama sebagai bentuk kebersamaan. ${ }^{60}$

\section{Kesimpulan}

Berdasarkan temuan penelitian dalam konteks toleransi agama sebagai pendekatan misi di Indonesia harus mendapat respon yang positif khususnya bagi kekristenan. Perbedeaan keyakinan kepercayaan agama-agama di Indonesia merupakan suatu keistemewaan untuk mewujudkan kebersamaan. Maka sudah seharusnya bagi umat Kristen menyadari panggilan Allah bagi dirinya dalam iman percayanya kepada Yesus melalui ketaatan kasih Allah dan sesamanya yang berdampak pada kesatuan dan persatuan bangsa Indonesia. Konsep toleransi beragama merupakan sikap menerima orang yang berbeda agama dengan menghargai dan menghormati kepercayaan/agamanya. Dengan demikian

${ }^{60}$ Dorkas Orienti Daeli and Sonny Eli Zaluchu, "Analisis Fenomenologi Deskriptif Terhadap Panggilan Iman Kristen Untuk Kerukunan Antar Umat Beragama Di Indonesia," SUNDERMANN: Jurnal Ilmiah Teologi, Pendidikan, Sains, Humaniora Dan Kebudayaan 1, no. 1 (2019): 44-50. 
tulisan ini dibangun pada perbedaan keyakinan kepercayaan dari setiap agama. Maka toleransi beragama merupakan bagian penting untuk mencapai kerukunan umat beragama yang diwujud nyatakan dalam intaraksi sosial pada nilai kemanusiaan, tanpa ada klaim kebenaran tertentu yang paling benar dari setiap agama tertentu.

Kenyataan dari sikap toleransi agama dapat dipandang sebagai tantangan sekaligus peluang untuk dapat membagun hubungan yang baik dalam kebersamaan. Dapat dikatakan peluang bagi keKristenan jika konsep toleransi agama memungkinkan kekristenan menghadirkan misi sebagai hati Allah yang bersumber dari Allah bagi umatnya dalam pemberitaan Injil. Maka melalui kesempatan terhadap konsep toleransi agama perlu direspon dalam sikap kemanusian yang didasari pada kasih Yesus dengan dibentuk secara pertemuan dialogis dalam interaksi sosial dan melaluinya umat Tuhan dapat melibatkan yang mampu mengimplementasikan toleransi beragama sebagai pendekatan dalam pelayanan misi. Kemudian ditunjukkan dalam iman percaya dan diresponi pada ketaatan akan kasih Allah kepada sesama manusia dalam perbedaan keyakinan tanpa menindas keyakinan agama lain. Pelayanan misi akan berjalan dengan efektif jika dilakukan atas dasar kebenaran firman Allah untuk memberitakan kabar keselamatan itu kepada semua orang dalam konteks toleransi agama.

\section{Rujukan}

Abdulkarim, Aim. Pendidikan Kewarganegaraan "Membangun Warga Negara Yang Demokratis. Jakarta: Grafindo Media Pratama, 2015.

Al-Barry, M. Dahlan Y. Kamus Induk Istilah Ilmiah. Surabaya: Target Press, 2003.

Andreas Kristianto, Aan Anshori, Yoses Rezon S., Dkk. Jalan Lain Perdamaian Refleksi Kolektif Para Penggiat Keragaman. Jakarta: Grafika Kreasindo, 2016.

Anggraeni, Dewi, and Siti Suhartinah. "Toleransi Antar Umat Beragama Perspektif KH. Ali Mustafa Yaqub." Jurnal Studi Al-Qur'an 14, no. 1 (2018): 59-77.

Bosch, David J. Tranformasi Misi Kristen. Jakarta: BPK Gunung Mulia, 1998.

Casram, Casram. "Membangun Sikap Toleransi Beragama Dalam Masyarakat Plural." Wawasan: Jurnal Ilmiah Agama Dan Sosial Budaya 1, no. 2 (2016): 187-198.

Daeli, Dorkas Orienti, and Sonny Eli Zaluchu. "Analisis Fenomenologi Deskriptif Terhadap Panggilan Iman Kristen Untuk Kerukunan Antar Umat Beragama Di Indonesia." SUNDERMANN: Jurnal Ilmiah Teologi, Pendidikan, Sains, Humaniora Dan Kebudayaan 1, no. 1 (2019): 44-50.

Effendi, Djohan. Merayakan Kebebasan Beragama. Jakarta: Indonesian Conference on Religion and Peace, 2009.

Iskandar, Pranoto. “The Pancasila Delusion.” Journal of Contemporary Asia 46, no. 4 (2016): 723-735.

James, Michael D. A. Happiness and The Art of Being. India: Create Space, 2012.

Kridalasana, Harimurti. Kamus Sinonim Bahasa Indonesia. Flores: Nusa Inda, 1977.

Kuiper, Arie de. Misiologia. Jakarta: BPK Gunung Mulia, 2010.

Lumintang, Stervri. I. Theologia Dan Misiologia Reformed. Malang: Departemen Literatur PPII, 2006.

Lumintang, Stervri. I. Re-Indonesianisasi Bangsa. Batu: Petrus Octavianus Institute, 2009.

Lumintang, Stevri I. Teologi \& Misiologia Reformed. Batu: Departemen Literatur YPPII, 2006.

- - - Theologia Abu-Abu: Pluralisme Agama, Edisi Revisi. Malang: Gandum Mas, 2009.

Netland, Harold. Encountering: Religious Pluralism. Tantangan Bagi Iman Dan Misi Kristen. Malang: Literatur SAAT, 2015.

Nisvilyah, Lely. "Toleransi Antarumat Beragama Dalam Memperkokoh Persatuan Dan Kesatuan Bangsa (Studi Kasus Umat Islam Dan Kristen Dusun Segaran Kecamatan Dlanggu Kabupaten Mojokerto)." Kajian Moral dan Kewarganegaraan 2, no. 1 (2013): 
382-396.

Noorsena, Bambang. Jangan Sebut Saudaramu Kafir. Malang: Institute for Syriac Christian Studies (ISCS), 2008.

Oentoro, Jimmy B. Indoneisa Satu, Indonesia Beda, Indonesia Bisa. Jakarta: PT Gramedia Pustaka Utama, 2010.

Packer, J. I. Penginjilan Dan Kedaulatan Allah. Surabaya: Penerbit Momentum, 2003.

Pancasila, Pusat Studi. Membangun Kedaulatan Bangsa Berdasarkan Nilai-Nilai Pancasila: Pemberdayaan Masyarakat Dalam Kawasan Terluar, Terdepan Dan Tertinggal (3T). Yogyakarta: Universitas Gadjah Mada, 2015.

Puar, Yusuf A. Panca Agama Di Indonesia. Jakarta: Pusaka Antara PT, 1977.

Purwaningsih, Eka. Pentingnya Hidup Rukun. Jakarta: PT Balai Pustaka, 2016.

Putranto, Bambang Eko. Misi Kristen. Yogyakarta: ANDI, 2007.

Rusydi, Ibnu, and Siti Zolehah. "Makna Kerukunan Antar Umat Beragama Dalam Konteks Keislaman Dan Keindonesian." Al-Afkar, Journal For Islamic Studies 1, no. 1, January (2018): 170-181.

Sairin, Weinata. Kerukunan Umat Beragama. Jakarta: BPK Gunung Mulia, 2006.

Schumann, Olaf Herbert. Agama Dalam Dialog: Pencerahan, Pendamaian Dan Masa Depan,. Jakarta: BPK Gunung Mulia, 2018.

Setijo, Pandji. Pendidikan Pancasila Perspektif Perjuangan Bangsa. Jakarta: Grasindo, 2012.

Siahaan, Daniel Syafaat. "Ketika Aku Dan Kamu Menjadi Kita: Dialog Misi Penginjilan Kristen Dengan Dakwah Islam Menggunakan Pendekatan Teologi Interkultural Dalam Konteks Indonesia." GEMA TEOLOGIKA: Jurnal Teologi Kontekstual dan Filsafat Keilahian 2, no. 1 (2017): 41-54.

Sitannggang, Cormentyna. Kamus Pelajar. Bandung: PT. Remaja Rosdakarya, 2003.

Suadnyana, Ida Bagus Putu Eka. "Ajaran Agama Hindu Dalam Cerita Batur Taskara." Sanjiwani: Jurnal Filsafat 11, no. 2 (2020): 232-244.

Suparman. Pancasila. Jakarta: PT Balai Pustaka (Persero), 2010.

Suryan, Suryan. "Toleransi Antarumat Beragama: Perspektif Islam." Jurnal Ushuluddin 23, no. 2 (2017): 185-200.

Suwarno, P.J. Pancasila Budaya Bangsa Indonesia. Yogyakarta: Kansius, 1993.

Tampenawas, Alfons Renaldo, Erna Ngala, and Maria Taliwuna. "Teladan Tuhan Yesus Menurut Injil Matius Dan Implementasinya Bagi Guru Kristen Masa Kini." EDULEAD: Journal of Christian Education and Leadership 1, no. 2 (2020): 214-231.

Tanuwibowo, Budi S. Agama Dan Negara, Perspektif Islam, Katolik, Hindu, Buddha, Konghucu, Protestan. Yogyakarta: Institut DIAN/Interfidei, 2002.

Tanya, Victor I. Pluralisme Agama Dan Problema Sosial. Jakarta: PT. Pustaka Cidesindo, 1998.

Tomatala, Dr. Yakob. Teologi Misi. Jakarta: YT Leadership Foundation, 2003.

Tong, Stephen. Theologi Penginjilan. Jakarta: LRII, 1988.

Usman, A. Rani. Etnis Cina Perantauan Di Aceh. Jakarta: Yayasan Pusaka Obor Indonesia, 2009.

Utomo, Bambang Ruseno. Hidup Bersama Di Bumi Pancasila "Sebuah Tinjauan Hubungan Islam Dan Kristen Di Indonesia. Malang: Pusat Studi Agama dan kebudayaan, 1993.

Wagner, C. Peter. Strategi Perkembangan Gereja. Malang: Gandum Mas, 2007.

Waluya, Bagja. Sosiologi: Menyelami Fenomena Di Masyarakat. Bandung: PT Setia Purna Inves, 2007.

Woly, Nicolas J. Perjumpaan Di Serambi Iman: Suatu Studi Tentang Pandangan Para Teolog Muslim Dan Kristen Mengenai Hubungan Antaragama. Jakarta: BPK Gunung Mulia, 2010.

Yewangoe, Andreas A. Agama Dan Kerukunan. Jakarta: BPK Gunung Mulia, 2009.

Zaluchu, Sonny Eli. "Strategi Penelitian Kualitatif Dan Kuantitatif Di Dalam Penelitian 
Agama." Evangelikal: Jurnal Teologi Injili dan Pembinaan Warga Jemaat 4, no. 1 (2020): 28-38.

Kamus Besar Bahasa Indonesia Edisi III. Jakarta: Balai Pustaka, 2001. 